
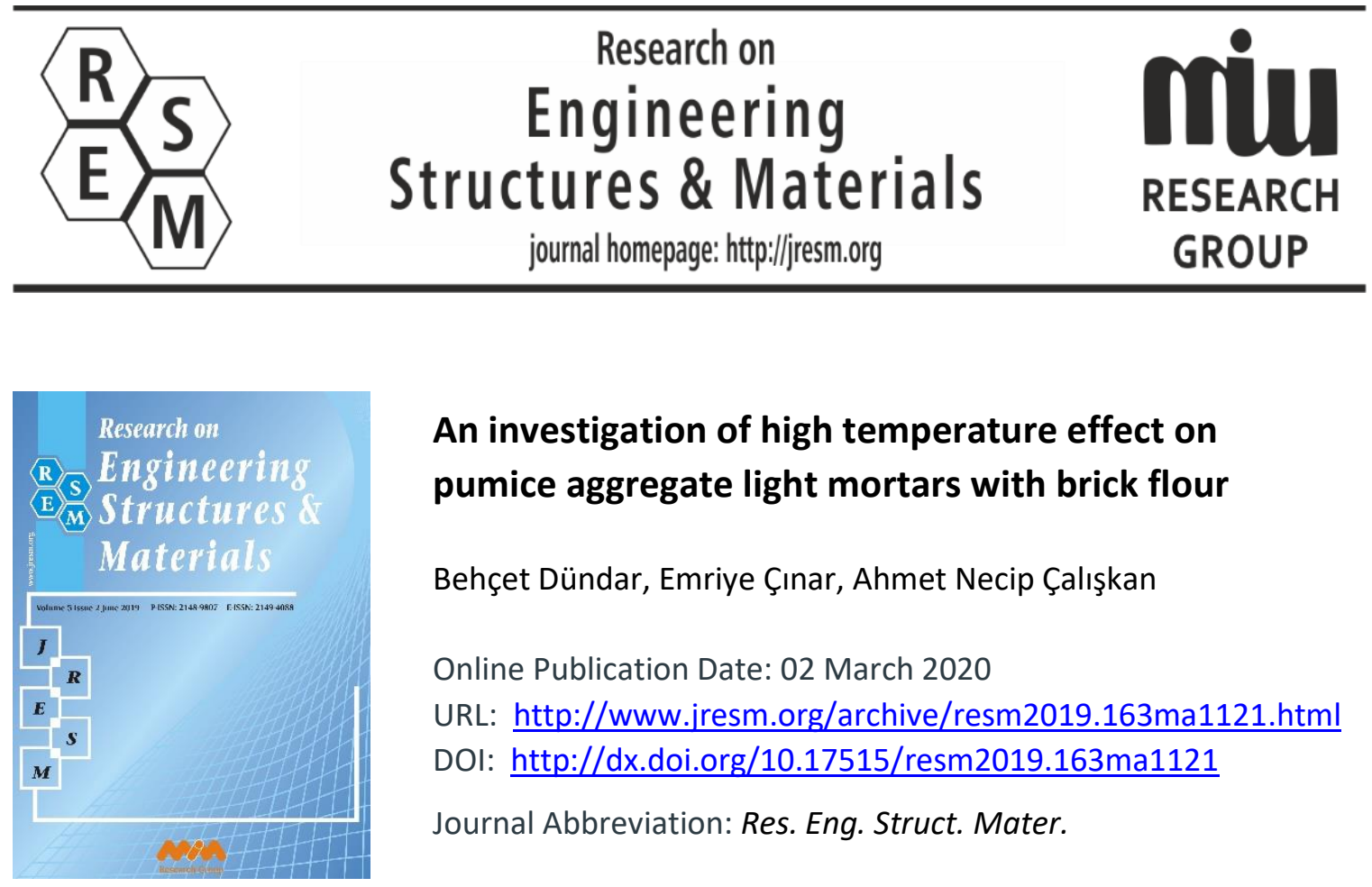

\title{
An investigation of high temperature effect on pumice aggregate light mortars with brick flour
}

Behçet Dündar, Emriye Çınar, Ahmet Necip Çalışkan

Online Publication Date: 02 March 2020

URL: http://www.jresm.org/archive/resm2019.163ma1121.html

DOI: http://dx.doi.org/10.17515/resm2019.163ma1121

Journal Abbreviation: Res. Eng. Struct. Mater.

\section{To cite this article}

Dundar B, Cinar E, Caliskan AN. An investigation of high temperature effect on pumice aggregate light mortars with brick flour. Res. Eng. Struct. Mater., 2020; 6(3): 241-255.

\section{Disclaimer}

All the opinions and statements expressed in the papers are on the responsibility of author(s) and are not to be regarded as those of the journal of Research on Engineering Structures and Materials (RESM) organization or related parties. The publishers make no warranty, explicit or implied, or make any representation with respect to the contents of any article will be complete or accurate or up to date. The accuracy of any instructions, equations, or other information should be independently verified. The publisher and related parties shall not be liable for any loss, actions, claims, proceedings, demand or costs or damages whatsoever or howsoever caused arising directly or indirectly in connection with use of the information given in the journal or related means.

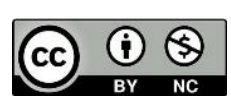

Published articles are freely available to users under the terms of Creative Commons Attribution - NonCommercial 4.0 International Public License, as currently displayed at here (the "CC BY - NC"). 


\title{
Research on Engineering Structures \& Materials
}

journal homepage: http://jresm.org

\section{An investigation of high temperature effect on pumice aggregate light mortars with brick flour}

\author{
Behçet Dündar a, Emriye Çınar *, b, Ahmet Necip Çalışkan ${ }^{c}$ \\ Civil Engineering Department, University of Osmaniye Korkut Ata, Osmaniye, Turkey
}

\begin{tabular}{|c|c|}
\hline Article Info & Abstract \\
\hline $\begin{array}{l}\text { Article history: } \\
\text { Received } 21 \text { Nov } 2019 \\
\text { Revised } 10 \text { Feb } 2020 \\
\text { Accepted } 12 \text { Feb } 2020\end{array}$ & $\begin{array}{l}\text { In this study, physical and mechanical properties of pumice aggregate } \\
\text { substituted with brick flour as mineral additive and light mortars were } \\
\text { investigated. At the preparation of mortars, pumice }(0-4 \mathrm{~mm}) \text { as a fine aggregate } \\
\text { and CEM I } 42.5 \mathrm{R} \text { Portland Cement were used. Standard mortar mixing ratios } \\
\text { were taken as fine aggregate/Cement/Water }=3 / 1 / 0.5 \text { and pumice aggregate is }\end{array}$ \\
\hline $\begin{array}{l}\text { Keywords: } \\
\text { Light Mortar; } \\
\text { Pumice; } \\
\text { Brick Flour; } \\
\text { High Temperature }\end{array}$ & $\begin{array}{l}\text { used as a fine aggregate. Brick flour, which is used as mineral additive, is } \\
\text { substituted with } 0 \%, 10 \%, 20 \% \text { and } 30 \% \text { by weight of cement. The flow values } \\
\text { of produced mortars were determined while they were in fresh form. Mortar } \\
\text { samples were cured in standard cure pool for } 28 \text { days. Flexural and compressive } \\
\text { strengths of the mortar samples which were cured for } 7 \text { days, were measured. } \\
\text { Physical properties such as water absorption, porosity and unit volume weight } \\
\text { of } 28 \text { days cured mortars were determined and flexural and compressive } \\
\text { strengths were calculated. At the end of } 28 \text { th day samples which were reached } \\
\text { its final strength, were exposed to } 200{ }^{\circ} \mathrm{C}, 400{ }^{\circ} \mathrm{C}, 600{ }^{\circ} \mathrm{C} \text { and } 800{ }^{\circ} \mathrm{C} \text { heats in High } \\
\text { Temperature Oven. With determining of flexural and compressive strengths } \\
\text { after heating, strength loss between before and after heating was designated. It } \\
\text { is observed that the flexural and compressive strengths were decreased with } \\
\text { increasing the ratio of Brick Flour. At all temperatures, it is occurred that the } \\
\text { ultrasound speed was decreased. With increasing of temperatures, ultrasound } \\
\text { speed values were reduced. }\end{array}$ \\
\hline
\end{tabular}

(C) 2020 MIM Research Group. All rights reserved.

\section{Introduction}

Nowadays, to solve housing and transportation problems effectively due to population increasing and limitation of land, Highrise buildings and underground construction needs are increasing rapidly. With developing technologies, it is observed that buildings provide more comfort and qualitive service. Thanks to this technology new equipment, systems and materials such as electrical applications and gas usage, are more preferred. However, in our daily life, these preferences may be increased of the fire possibility in buildings. Fire can be caused on structure elements even though it was not a risk for life, and it can directly effect on structure safety and service life [1]. Cement is one of other binding materials which is used the most in Civil Engineering Sector. Cement consumption is increasing as well as the rapidly increasing of building sector. Although fully domestic raw materials are used in cement industry, production is negatively affected by high energy cost and due to process causes $\mathrm{CO}^{2}$ production, this has a big role in global warming. Because of this reason, used energy of cement industry and environmental impacts are one of the constantly debated topics of both scientific and world agenda. In addition to this, rehabilitation of cement process is continued, and search of raw materials which lead to make better quality, efficient and economic cement, is ongoing [2-3]. The use of doped cements in the construction sector has become more preferable today due to the economic and technical advantages they provide, as well as the indirect benefits in reducing $\mathrm{CO} 2$ emissions by reducing clinker production. Most of these

${ }^{*}$ Corresponding author: emriyecinar@osmaniye.edu.tr

a orcid.org/0000-0003-0724-9469; b orcid.org/0000-0002-9435-2968; c orcid.org/0000-0002-9497-5209

DOI: http://dx.doi.org/10.17515/resm2019.163ma1121

Res. Eng. Struct. Mat. Vol. 6 Iss. 3 (2020) 241-255 
materials are mineral additives with pozzolanic properties [4]. Pozzolans; with its advantages such as economic efficiency in cement, reduction of permeability, control of alkali aggregate development, chemical resistance, lightness, utilization of wastes, reduction of drying shrinkage of concrete and increase of strength, it is added to the concrete as a direct contribution to cement or to be added to a part of cement[5]. In recent years, to provide high temperature resistance, mineral additives are used in mixtures. Fly ashes, blast furnace slag and silica fume are among them and commons [6-7]. Also it is known that pozzolanic materials provides resistance of fire to cement based materials [8]. In world history, the first produced construction material brick, is used on essential buildings through history. Brick that is produced by using clay, is mostly used construction materials thanks to its positive properties such as durability and strength, low sound and heat permeability and fire resistance [9]. Brick is widely used and produced in agricultural structures in rural areas as well as in cities due to the fact that suitable soil is abundant and this material enables cheap and easy production [10]. In Turkey, some buildings such as animal shelters and agricultural product storages are mostly built as one story and by using prefabricated materials. Brick is the one of these prefabricated materials and commonly used [11-12]. Brick flour is one of the pozzolanic additives added to both mortar and concrete. Increasing the production of brick in industry, has brought many problems with itself. Important one of these problems is remained product waste after production. Breaks occur during brick production and transportation and these broken bricks are separated as waste [13]. To remove out brick wastes outside causes harming on efficient farm areas and negative impact on country economy. Moreover, it takes thousand years.to recover these harmed farm areas itself and this leads disruption of ecological balance on soil [14]. Investigations and researches show that brick waste consists $\% 10$ of total production [15]. Researches are done in many countries for how to use these product wastes due to increasing of production wastes. By reducing the amount of waste materials, the main materials are tried to be minimized by substituting the main materials for environmental damage. Thus, natural resources will be better used and environmental pollution will be reduced with the use of waste materials [16]. The reason for the loss of strength at high temperatures is the decomposition of hydration products. The researchers stated that the decomposition of the cemented matrix started above $105^{\circ} \mathrm{C}$. The first step of chemical and physical separation is to release water in the pores and chemically bound water in the structure of calcium silicate hydrate (C-S-H) gels. This process is called dehydration [17]. In this step, other hydrates and ettringite also begin to decompose. Also, depending on the origin and type, aggregates may begin to be affected [18]. At about $300-400{ }^{\circ} \mathrm{C}$, the chemically bonded intermediate layer water in the $\mathrm{C}-\mathrm{S}-\mathrm{H}$ gel evaporates. In addition, the first microfractures begin to appear in $\mathrm{Ca}(\mathrm{OH}) 2$ and anhydrite cement regions [19]. At this stage $\mathrm{Ca}(\mathrm{OH}) 2$ decomposes into $\mathrm{CaO}$ and $\mathrm{H} 2 \mathrm{O}$. In the heating step, the decomposition of $\mathrm{Ca}(\mathrm{OH}) 2$ is not a critical reaction in terms of power. In the cooling process, however, $\mathrm{CaO}$ can be rehydrated to $\mathrm{Ca}(\mathrm{OH}) 2$ and this rehydration produces a significant volume expansion of about $44 \%$ [20-21]. At $500-600^{\circ} \mathrm{C}$, the carbonates begin to decompose and are known to cause irreversible damage to concrete. This is because an important part of the main binder phase of concrete, namely C-S-H gels, is decomposed. In general, above $800{ }^{\circ} \mathrm{C}$, almost all constituents of concrete break down, leading to significant strength and weight loss [22]. As the thermal properties of cement paste and aggregates are not exactly the same, it creates internal stresses and generally results in cracking [23]. The use of mineral admixtures has been investigated in order to increase the durability of cement-based materials both in the evaluation of waste products and in the face of a fire disaster that may be encountered at any time. In addition to the usual mineral additives, the usability of Brick Flour in mortar samples was investigated and the effect of physical and mechanical properties on mortar properties were investigated. In this study, pumice aggregate mortar samples were produced by replacing $10 \%, 20 \%$ and $30 \%$ by weight of brick flour to cement. The produced mortar samples were removed from the mold after 24 hours and left to stand in the curing pool. Fresh processability of mortar samples, 7 and 28 days bending and compressive strength tests, 
ultrasound, water absorption, porosity, unit volume weight and high temperature tests were performed. The mortar samples, which were filled for 28 days, were kept at $200{ }^{\circ} \mathrm{C}, 400{ }^{\circ} \mathrm{C}$, $600{ }^{\circ} \mathrm{C}$ and $800{ }^{\circ} \mathrm{C}$ for one hour while high temperature test was performed. After the $0 \%$, 10\%, 20\%, 30\% Brick Flour samples were removed from the high temperature furnace, bending and pressure values, water absorption, porosity, unit volume weight tests were performed and the data were taken.

\section{Experimental Studies}

\subsection{Used Materials}

Cement is one of the mortar components, is taken from ÇIMSA cement factory as CEM I 42.5 R type and produced according to TS EN 197-1 [24]. Chemical analysis of used cement is taken from producer cement factory and physical and chemical properties were given in Table 1.

Table 1 Physical and Chemical properties of CEM I 42.5 R type cement and Brick Flour

\begin{tabular}{ccc}
\hline Chemical Analysis (\%) & CEM I 42.5R & BF \\
\hline $\mathrm{CaO}(\%)$ & 64.7 & 3.50 \\
$\mathrm{SiO}_{2}(\%)$ & 20.7 & 58.50 \\
$\mathrm{AL}_{2} \mathrm{O}_{3}(\%)$ & 5.55 & 16.50 \\
$\mathrm{Fe}_{2} \mathrm{O}_{3}(\%)$ & 2.9 & 8.00 \\
$\mathrm{MgO}(\%)$ & 2.68 & 0.15 \\
$\mathrm{SO}_{3}(\%)$ & 2.76 & 0.00 \\
$\mathrm{Na}_{2} \mathrm{O}(\%)$ & 0,25 & 1.00 \\
$\mathrm{~K}_{2} \mathrm{O}(\%)$ & 0,46 & 2.41 \\
Loss on ignition (\%) & 3.26 & - \\
Fineness (m²) & 31020 & 29700 \\
Volume Expansion (mm) & 1 & - \\
Beginning of Set (min) & 260 & - \\
Ending of Set (min) & 300 & - \\
\hline
\end{tabular}

In the experimental study, city network water of Osmaniye province complying with TS EN 1008 was used in the mixture of mortar samples produced [25]. pumice deposits in Turkey are concentrated in Urgup Avanos and Kayseri's Talas-Tomarza-Devel and Osmaniye. It contains numerous pores from the macro scale to the micro scale due to the sudden release of the gases during pumice formation and sudden cooling. As the pores are generally unconnected, they are lightweight, can swim for a long time in water, have low permeability and have high insulation. It has a chemical content of up to $75 \%$ silica. The SiO2 content of the rock gives the rock abrasive properties. Al203 composition gives high resistance to fire and heat [26]. Pumice which is used to produce mortar is given in Fig. 1, is obtained from Osmaniye province Toprakkale district Tüysüz municipality. 


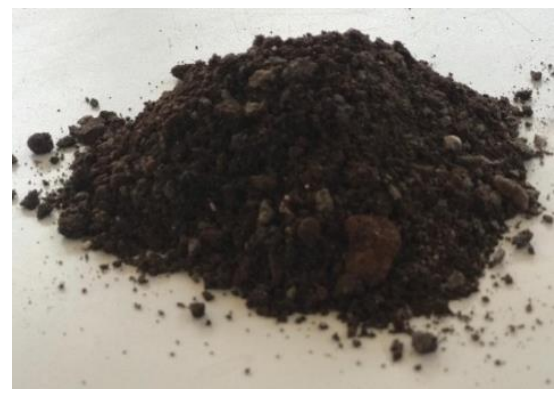

Fig. 1 Osmaniye Pumice

Chemical analysis of maximum $4 \mathrm{~mm}$ grain diameter Pumice Aggregate, is given in Table 2.

Table 2 Chemical analysis of used Pumice

\begin{tabular}{cc}
\hline Composition & Average \\
\hline $\mathrm{SiO}$ & 45.95 \\
$\mathrm{AhO}$ & 19.95 \\
$\mathrm{Fe}_{2} \mathrm{O}$ & 7.53 \\
$\mathrm{CaO}$ & 13.23 \\
$\mathrm{MgO}$ & 6.24 \\
$\mathrm{Na}_{2} \mathrm{O}+\mathrm{K}: 0$ & 6.69 \\
Other & 0.41 \\
Total & 100.00 \\
\hline
\end{tabular}

In this study, firstly standard brick is formed to $4 \mathrm{~mm}$ size by using crusher then by using ringed grinder, $4 \mathrm{~mm}$ sized brick is formed to $24-40 \mu$ and brick flour was used as mineral additive and given in Fig. 2.

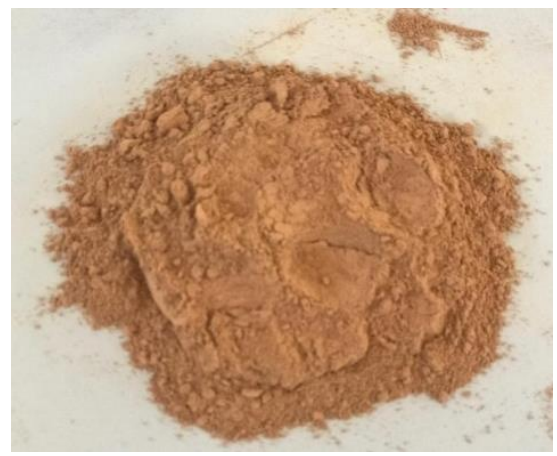

Fig. 2 Brick Flour

Inside brick, there is no chemical material which can harm human health or environment. Therefor some bricks which is damaged during the process of production or transportation, are grinded and used for floor elements, tennis courts, park walking ways, bicycle roads and garden arrangements. 


\subsection{Sample Production}

In this study, 4 pumice aggregate samples are produced by adding brick flour to cement by weight of $10 \%, 20 \%, 30 \%$. In mixtures, pumice is used as a fine aggregate then mixtures are waited for 24 hours in 40x40x160mm molds according to TS EN 13369 (2018) rules. After that molds are placed in curing pool. Flexural and compression tests are applied on 7th and 28th days samples. Reference sample is produced by only cement, aggregate and water without brick flour [29]. Materials that are used in experiment are given in Table 3.

Table 3 Materials and Sample names and weights in Experiment (gr)

\begin{tabular}{cccccc}
\hline Sample Name & Explanation & Aggregate & Water & Cement & Brick Flour \\
\hline BF0 & Reference & 850 & 250 & 450 & 0 \\
BF10 & \%10 BF added mortar & 850 & 250 & 405 & 45 \\
BF20 & \%20 BF added mortar & 850 & 250 & 360 & 90 \\
BF30 & \%30 BF added mortar & 850 & 250 & 315 & 135 \\
\hline
\end{tabular}

Spread values for each mixture were measured on the Flow Table of the mixtures. After the spread values were taken, the lubricated molds were placed on the cement shaking table and concrete mortar was poured into the molds in two stages [30].

\subsection{Flow-Table Test}

Flow-Table Test is carried out to determine the consistency and spread value of fresh mortar immediately after mixing of mineral binder and dense (normal) aggregate or light aggregates. The fresh mortar placed in the mold used in the test is taken by slowly pulling the mold vertically upwards in the test stage and the mass of the mortar remaining on the circular plate is fell to 15 times at a constant frequency and approximately 15 times per second. Flow-Table Test was applied to fresh mortar samples according to TS EN 1015-3 (2010) standard [31].

\subsection{Water Absorption and Porosity Tests}

Porosity and water absorption properties were determined by using Archimedes principle scales on all series. At the end of 28 days, the concretes were removed from the curing pool and put into the basket in the scale and the data were recorded by means of Archimedes Scales. The surfaces were then dried with a cloth and their weights in the air were taken. Samples were dried in oven at $110^{\circ} \mathrm{C}$ for 24 hours. The samples from the oven were cooled until samples reaces room temperature and then the oven dry weights were weighed. Weight measurements were made on 3 samples for each series and their mean values were recorded [32].

\subsection{Compressive and Flexural Tests}

In all series, after 24 hours, it was cured for 7 and 28 days under standard curing conditions. Samples with high temperature applied and not applied after curing were subjected to bending and pressure tests with the device in Fig. 3 with the help of the device in Fig. 3 manufactured by Baz Makina with the capacity of 200 tons according to the Turkish standard [33]. In the study, TS EN 196-1 standard was used for determination of flexural-compressive strengths. Flexural-compressive determination of cements was carried out on 40x40×160 mm specimens in accordance with TS EN 196-1 as shown in Fig. 4 [34]. 


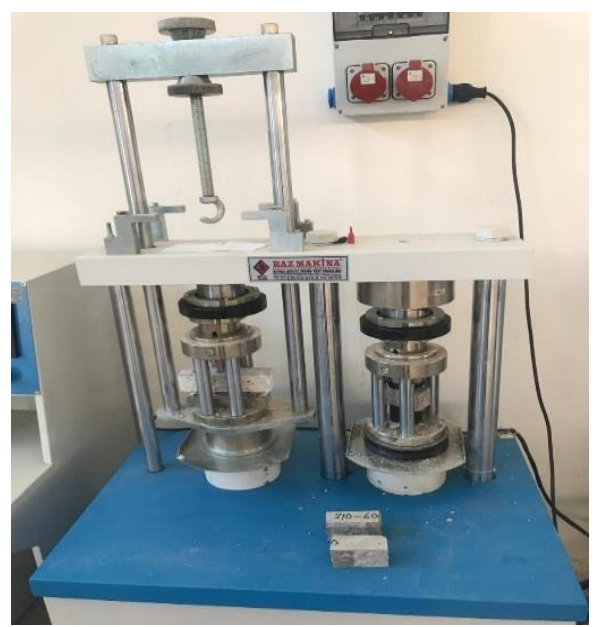

Fig. 4 Flexural and Compressive Strength Device

\subsection{Ultrasound Test}

The ultrasound pulse velocity measurements of the samples were made with the ultrasound test device (P-wave) in Fig. 5. The samples were kept in standard curing pool for 28 days and oven dried, ultrasound test was applied. The distance between the two surfaces of the samples was measured with the help of a calliper rule, and the surfaces to be measured were smooth with the ultrasound gel in order to avoid air gap. The sample was placed between the probes (donor-receiver) and aligned and the device was started. The transition time of the sound wave in the device is recorded. By using the intermediate distance between the probes and the sound transition velocity we recorded, ultrasound transition velocities were calculated by making the necessary calculations in the formula. The ultrasound test samples were then placed in a high temperature furnace and then stored at $200 \mathrm{C}, 400{ }^{\circ} \mathrm{C}, 600{ }^{\circ} \mathrm{C}$ and $800{ }^{\circ} \mathrm{C}$ temperatures according to standards [35].

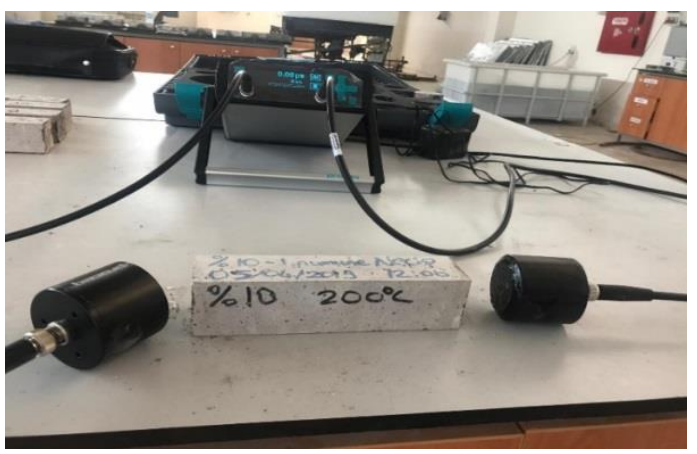

Fig. 5 Ultrasound test device

\subsection{Application of High Temperature on Samples}

High temperature application was carried out in accordance with the principles specified in TS EN 13501-1 (2013) standard. According to the standards, the actual fire environment is between $20-1000^{\circ} \mathrm{C}$ and occurs within $15-300$ minutes. The average temperature increase rate corresponds to $27.4 \mathrm{C} / \mathrm{min}$. However, it is not possible to increase the heat increase rate to $27.4^{\circ} \mathrm{C} / \mathrm{min}$ in such a short time for resistance furnaces. The mortar samples were applied at $200{ }^{\circ} \mathrm{C}, 400{ }^{\circ} \mathrm{C}, 600{ }^{\circ} \mathrm{C}$ and $800^{\circ} \mathrm{C}$ at a temperature of $10^{\circ} \mathrm{C} / \mathrm{min}$ in a laboratory oven with a capacity of $1800{ }^{\circ} \mathrm{C}$ and kept in the oven for 60 minutes at all temperatures. Samples were 
then allowed to cool to the temperature of the laboratory conditions. The samples subjected to high temperatures were re-tested after bending, pressure and ultrasound after cooling [36].

\section{Results and Discussion}

\subsection{Flow Test}

Flow values of samples that were produced for experimental study, were given in Table 4. It is observed that with increasing of Brick Flour ratio, flow values decreased. Also, with increasing the use of Brick Flour ratio, it is observed that workability is decreased.

Table 4 Flow values of fresh state mortar samples

\begin{tabular}{cc}
\hline Sample Name & Flow Values $(\mathrm{cm})$ \\
\hline$\% 0 \mathrm{BF}$ & 14.0 \\
$\% 10 \mathrm{BF}$ & 14.0 \\
$\% 20 \mathrm{BF}$ & 13.5 \\
$\% 30 \mathrm{BF}$ & 13.0 \\
\hline
\end{tabular}

\subsection{Porosity, Water Absorption and Weight per Unit of Volume}

Experimental results of samples that are produced for study, were given in Fig. 6. According to these results below, maximum it is found that $20 \%$ BF sample has the maximum porosity as $25 \%$. In comparison with Reference sample, it is observed that porosity has increased by $10 \%$.

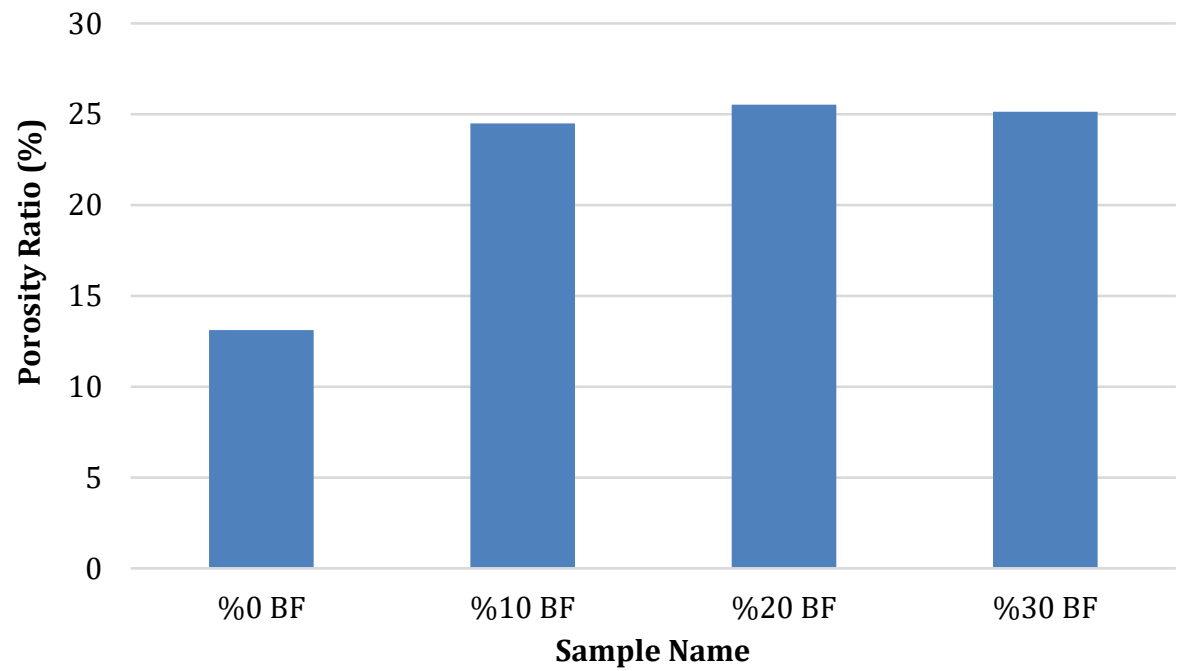

Fig. 6 Experimental Porosity Results

Water absorption ratios of samples that are cured for 28 days, are given in Fig. 7 as graph. When this graph is analysed, it is observed that $20 \% \mathrm{BF}$ samples has the maximum water absorption ratio as $14.30 \%$. In all series it is observed that with adding brick flour into cement, water absorption ratios were increased compare to reference sample. 
15

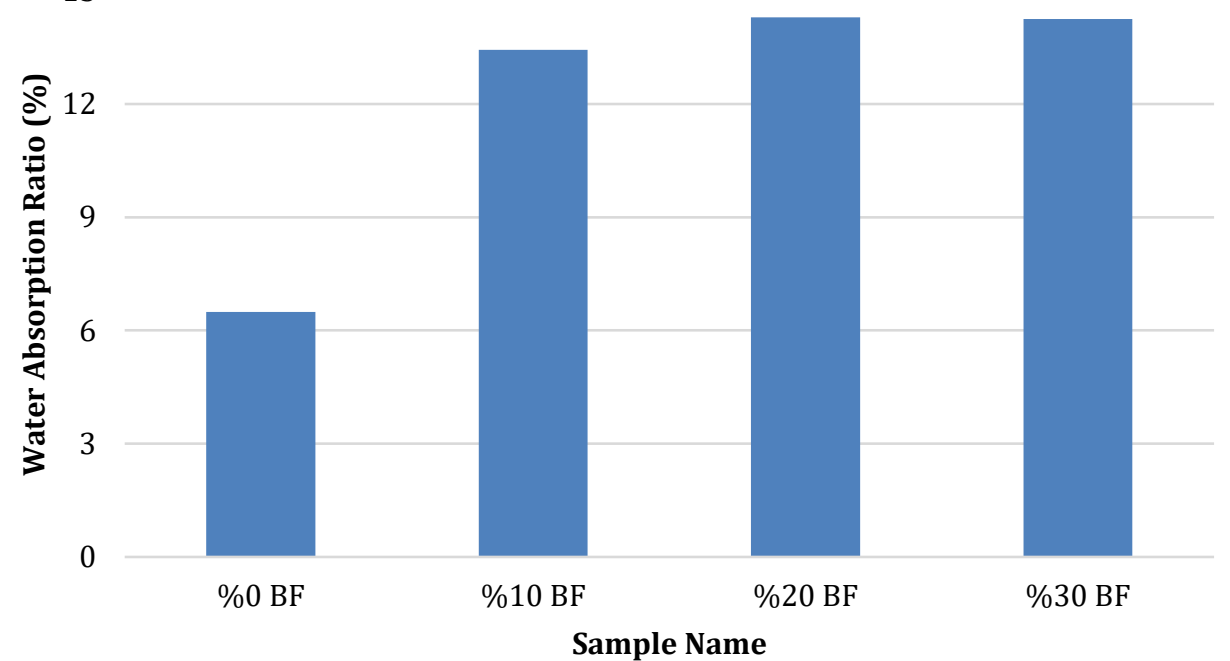

Fig. 7 Experimental Water Absorption Results

The relationship between porosity and water absorption is given in Fig. 8. The correlation coefficient between water absorption and porosity was found as $\mathrm{R}^{2}=0.9981$. From this result, it was determined that a strong relationship between these two physical properties.

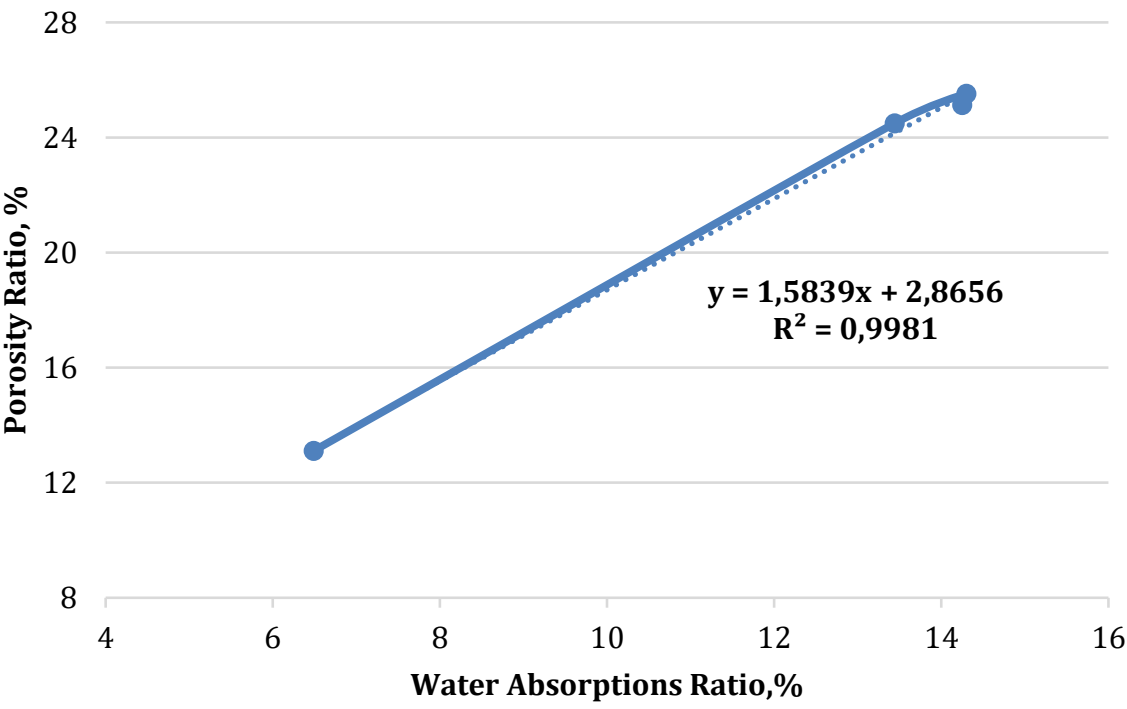

Fig. 8 The relationship between porosity and water absorption

Weight per unit of volume tests were done on produced samples and test results were shown in Fig. 9. According to these results, it is observed that the weight per unit of volume of samples has decreased with adding brick flour. In $20 \%$ BF sample unit volume weight was $1.78 \mathrm{gr} / \mathrm{cm} 3$ while it was $2.02 \mathrm{gr} / \mathrm{cm} 3$ in reference sample. 
2,5

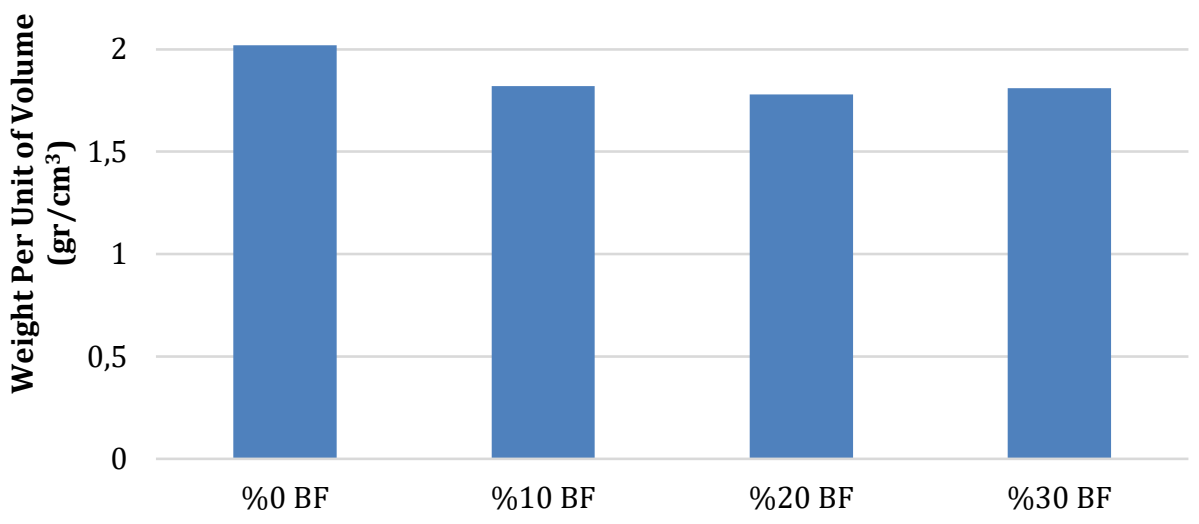

Sample Name

Fig. 9 Weight Per Unit of Volume Experimental Results

\subsection{Flexural and Compressive Strength}

7- and 28-days flexural strength test results are given in Fig. 10, is applied on produced samples. When these results are investigated, it is observed that flexural strength value in $10 \%$ BF sample is more than reference sample. Flexural Strength has increased up to $10 \%$ added BF however, it was observed that Flexural Strength was decreased at $20 \% \mathrm{BF}$ and $30 \% \mathrm{BF}$ added samples due to increasing of fine material amount. Also, increasing of fine material causes surface area. This situation leads mortar placement problems. It is found that on 7 th day reference sample compressive strength was $4.72 \mathrm{MPa}$ while $10 \%, 20 \%, 30 \%$ Brick Flour added samples were 5.83, 5.22 and $5.16 \mathrm{MPa}$ respectively. While the 28 day pressure value of the reference sample was $6 \mathrm{MPa}$, these values were found to be $6.52,6.05$ and 5.73 MPa in the samples which were replaced with 10\%, 20\%, 30\% cement and brick flour. When the compressive strength values of all series were examined, it was observed that the maximum value was in the substituted sample of $10 \%$ brick and the minimum value in the substituted sample of $30 \%$.

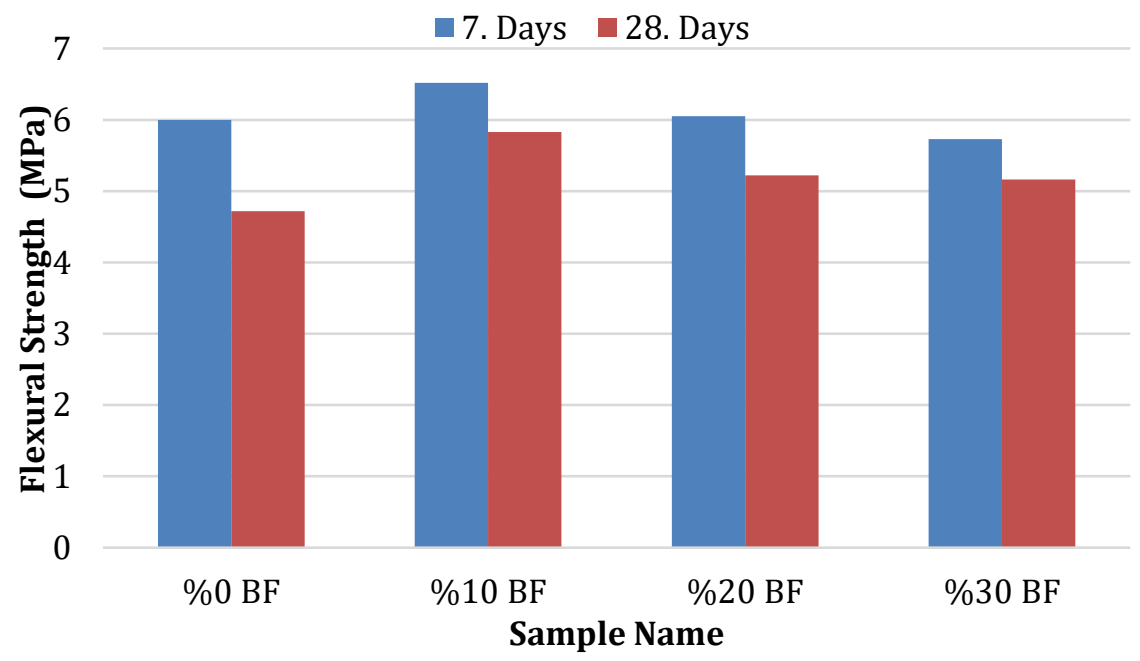

Fig. 10 Flexural Strength Values 
Samples were applied to Flexural Strength Test before and after high temperature application. Test results were given in Fig. 11. It is observed that after high temperature application on samples, strengths were decreased. Also increasing with temperature value causes further sample strength decline.

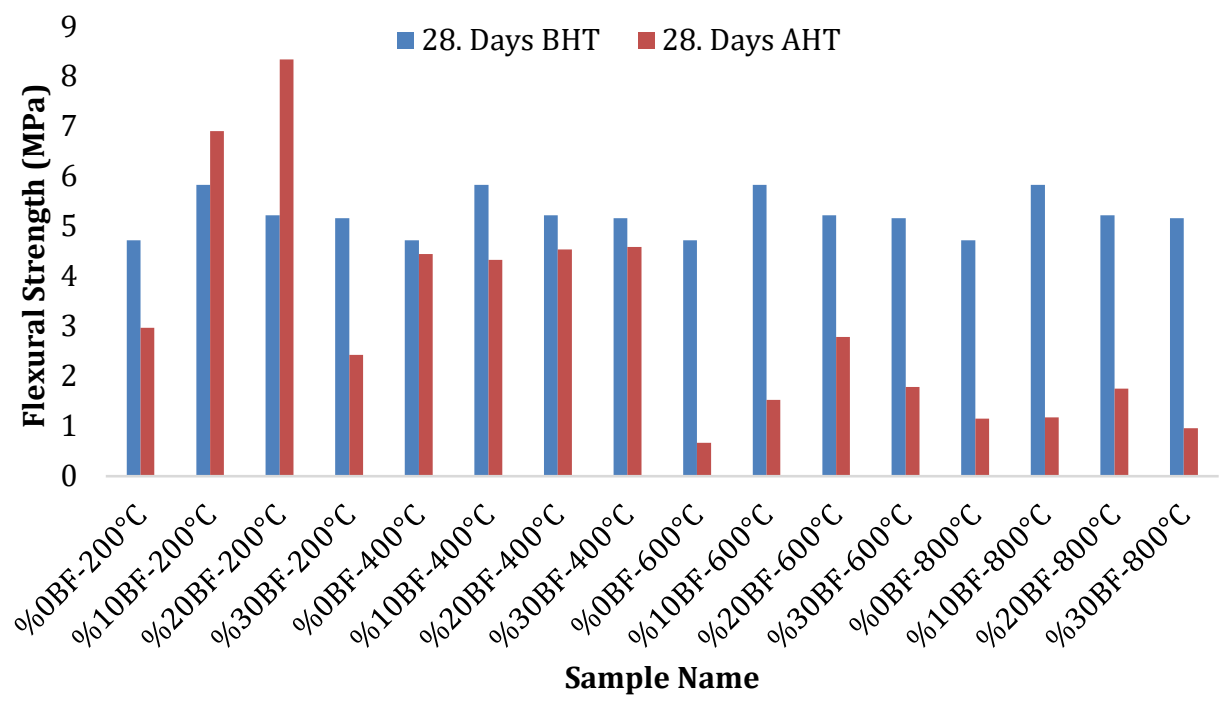

Fig. 11 Flexural Strength Before and After High Temperature Application

7 and 28 days compressive test results are given in Fig. 12, is applied on produced samples. When these results are investigated, it is observed that compressive strength of Brick Flour added is more than reference sample. It is found that on 7 th day reference sample compressive strength was $35.58 \mathrm{MPa}$ while 10\%, 20\%, 30\% Brick Flour added samples were $34.68,31.14$ and $28.78 \mathrm{MPa}$ respectively. While the 28 day pressure value of the reference sample was $45.56 \mathrm{MPa}$, these values were found to be 53.03, 46.51 and $39.53 \mathrm{MPa}$ in the samples which were replaced with $10 \%, 20 \%, 30 \%$ cement and brick flour. When the compressive strength values of all series were examined, it was observed that the maximum value was in the substituted sample of $10 \%$ brick and the minimum value in the substituted sample of $30 \%$.

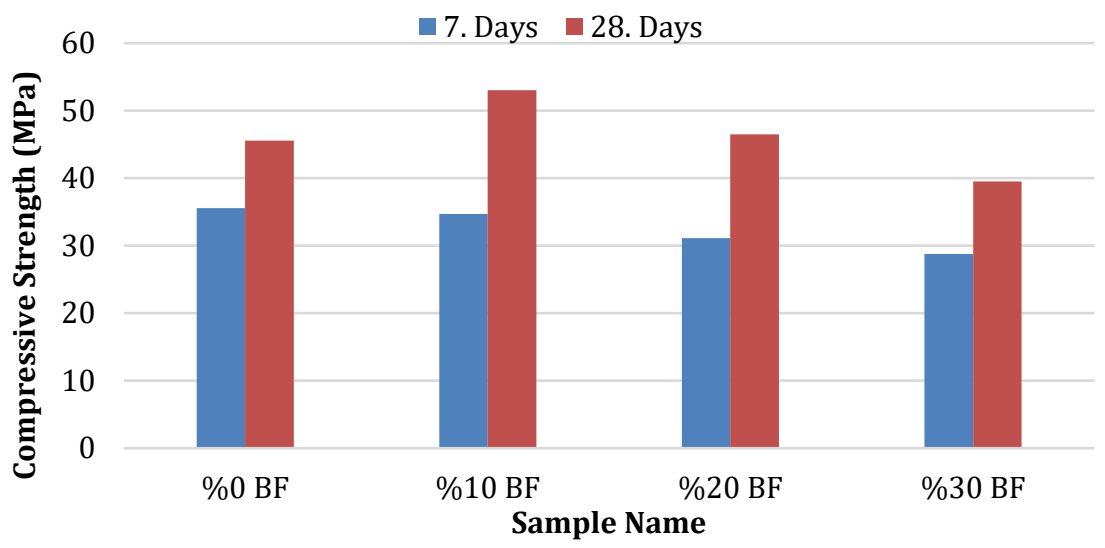

Fig. 12 Compressive Strength Experimental Results 
Samples were applied to Compressive Strength Test before and after high temperature application. Test results were given in Fig. 13. It is observed that after high temperature application on samples, compressive strengths were decreased. Also increasing with temperature value causes further sample compressive strength decline.

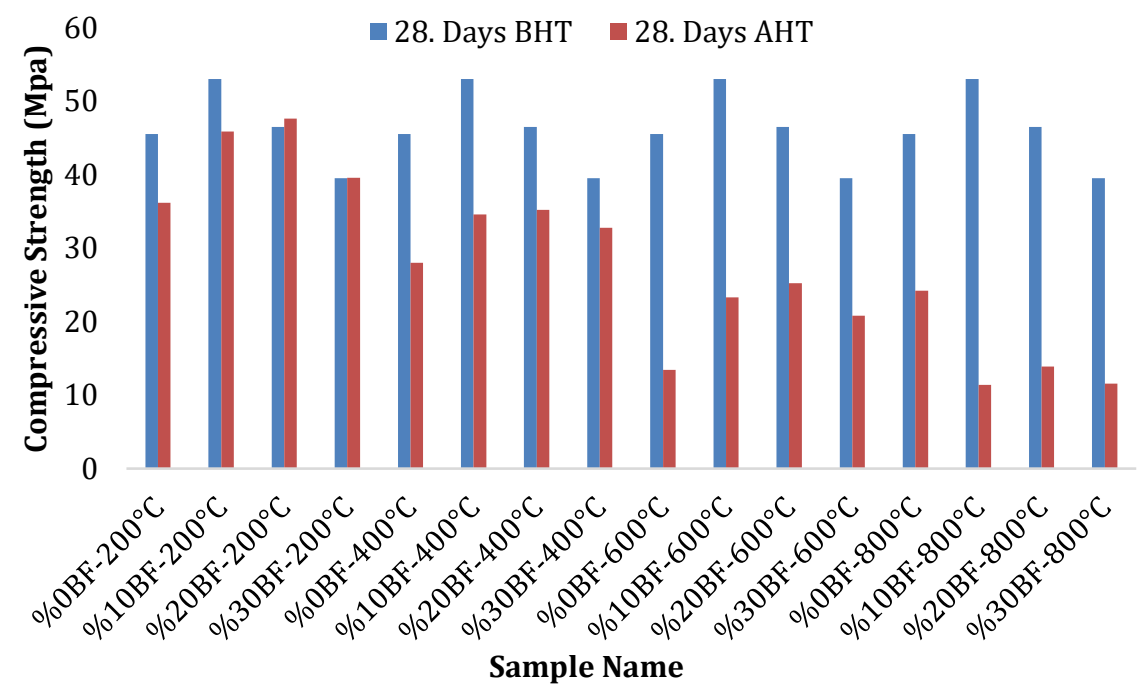

Fig. 13 Compressive Strength Before and After High Temperature Application

\subsection{Ultrasound Pulse Velocity}

The results of ultrasound before and after temperature according to the ratio of each brick flour are given in Fig. 14. When the effect of temperature on Ultrasound Pulse Velocity is investigated, it is observed that Ultrasound Pulse Velocity was decreased at all temperatures for all samples. With increasing temperature Ultrasound Pulse Velocity values were decreased. Due to Brick Flour is a fine material, it makes filling effect. Increases the surface area when the brick flour is substituted, increases the binding demand of the sample. With increasing demand, binding material is insufficient. This leads a cavitied structure. Ultrasound Pulse Velocity was decreased with strength declining. The velocity of the ultrasound passage was reduced due to the explosion of capillary cracks in the sample with a significant proportion of temperature.

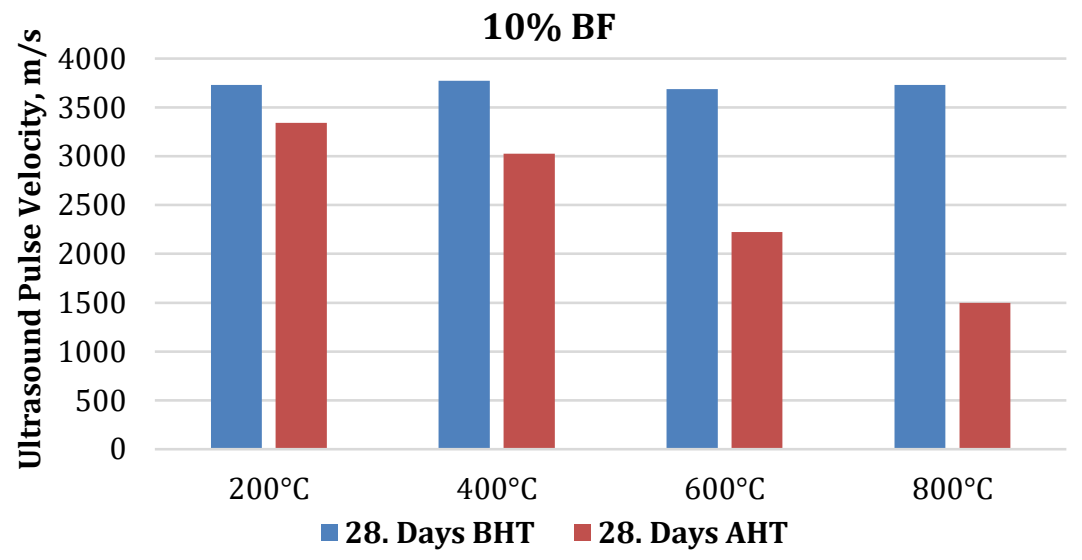

(a) 


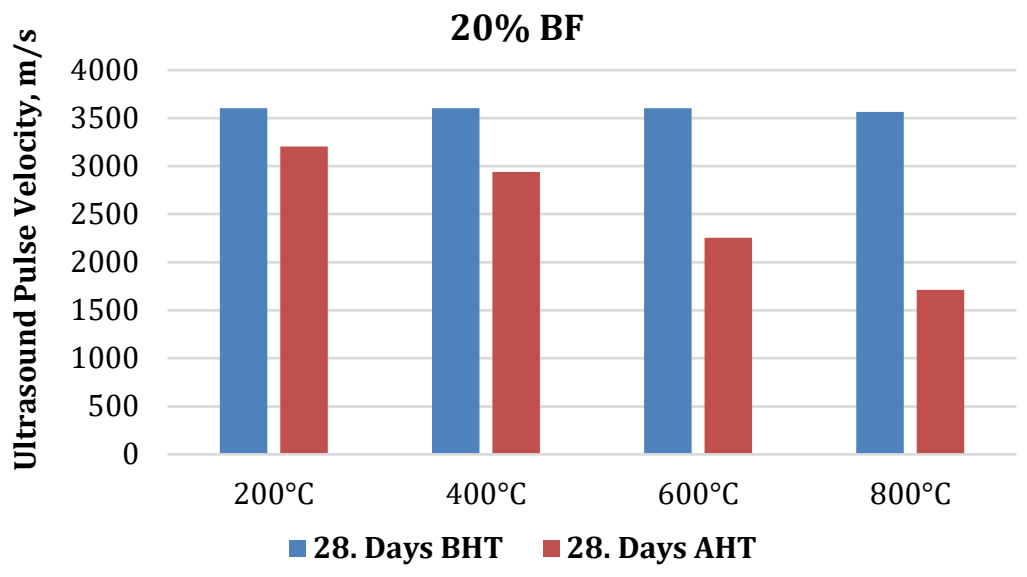

(b)

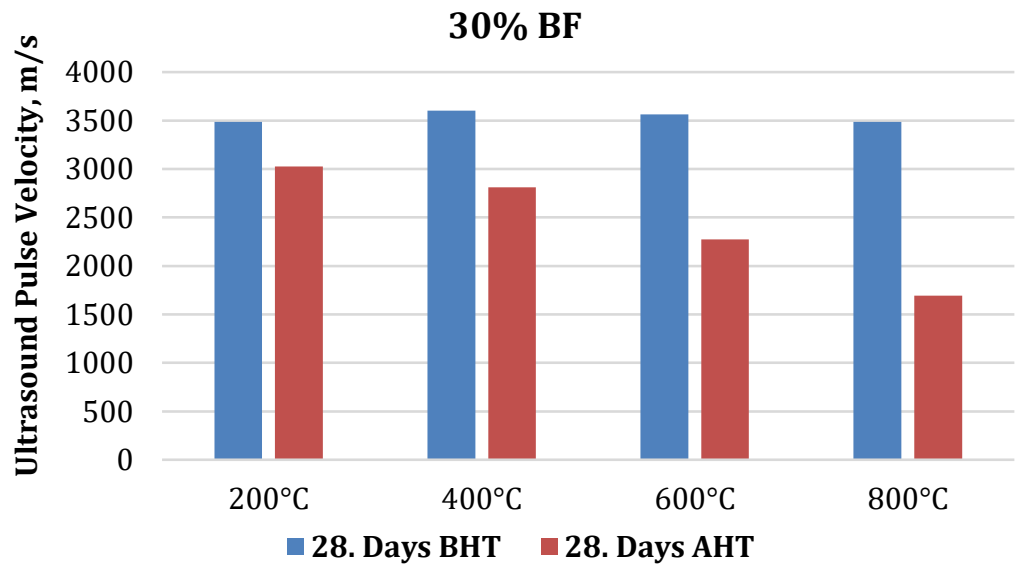

(c)

Fig. 14 Ultrasound Values After High Temperature Application of Mortar Samples, a;10\%BF, b;20\%BF, c;30\%BF

\section{Conclusions}

In this experimental and numerical study; physical and mechanical properties of pumice aggregate substituted with brick flour as mineral additive and light mortars were investigated. From the results of this study, the following conclusions can be drawn:

- When the flow values are investigated, it is observed that flow values were decreased with increasing BF ratio. This causes decreasing of workability.

- $\quad$ For mortar porosity values, it is found that $20 \%$ BF added mortar has the maximum porosity as $25 \%$. There was $10 \%$ increase in comparison to reference sample.

- In all sample series, water absorption ratio was increased as a result of adding Brick Flour and cement into mixture. 
- According to these results, weight per unit of volumes were decreased as a result of adding Brick Flour into mixture. The weight per unit of volume was $2.02 \mathrm{~g} / \mathrm{cm} 3 \mathrm{in}$ the reference sample and $20 \%$ brick flour added sample was reduced to $1.78 \mathrm{~g} / \mathrm{cm} 3$.

- When these results were investigated, it is observed that $10 \% \mathrm{BF}$ added sample has more flexural strength in comparison to reference sample. At the end of the 28th day, according to reference $10 \%$ brick flour added sample showed the maximum increase in comparison to other samples.

- All series showed that flexural strength decrease after High Temperature Application, in comparison with reference sample. It is observed that with increasing temperature decreases flexural strength of samples.

- When the results were examined, it was found that the compressive strength was $10 \%$ higher than the reference sample. The 7 -day pressure value of the reference sample was $35.58 \mathrm{MPa}$, while the values of $10 \%, 20 \%, 30 \%$ cement and brick flour added samples were $34.68,31.14$ and $28.78 \mathrm{MPa}$, respectively.

- While the 28-day pressure value of the reference sample was $45.56 \mathrm{MPa}$, these values were found to be 53.03, 46.51 and $39.53 \mathrm{MPa}$ in the samples with $10 \%, 20 \%, 30 \%$ cement and brick flour added respectively. When the compressive strength values of all series were examined, it was observed that the maximum value was in the sample with $10 \%$ brick flour added and in the sample with $30 \%$ brick flour added, this value decreased to $39.53 \mathrm{MPa}$.

- It is observed that Post-High temperature application compressive strengths were decreased compared to the reference sample.

- The results and recommendations obtained from this study, in which the addition of brick flour in cement mortar by weight and then its effect on the strength after high temperature, are listed below:

1. In the production of cement mortar, it is considered that the use of brick flour as a mineral additive will be suitable in terms of providing economic contribution by evaluating the wastes and reducing the consumption of cement which is an expensive material.

2. Brick flour that used in this study has been found to be usable in the production of admixture cement within the standards. $10 \%$ admixture cement has a positive effect on strength after 7 and 28 days. This rate is around $5 \%$.

\section{References}

[1] W. Wang, C. Lu, Y. Li, Q. Li, An investigation on thermal conductivity of fly ash concrete after elevated temperature exposure, Constr. Build. Mater. 2017; 148-157. https://doi.org/10.1016/i.conbuildmat.2017.05.068

[2] Yıldırım, E. Çorum'da Kullanılan Tuğla Atıklarının Tekrar Değerlendirilmesinin Araştırılması, Gazi Üniversitesi, Fen Bilimleri Enstitüsü, Yüksek Lisans Tezi, 2001; 78-83s, Ankara.

[3] Yılmaz, B. Na-CMC Polielektrolik İlavesinin Puzolanlı Çimento Özelliklerine Etkisi. Dumlupınar Üniversitesi, Fen Bilimleri Enstitüsü Dergisi, 2006; 11, 143- 154.

[4] Kırgız, M.S. Mermer ve Tuğla Endüstrisi Atıklarının Çimento Üretiminde Mineralojik Katkı Olarak Kullanılması. Gazi Üniversitesi, Fen Bilimleri Enstitüsü, Doktora Tezi, 2007; 228s, Ankara.

[5] Hansen TC. Recycling of demolished concrete and masonry. London: E\&FN SPON; 1992. 
[6] A.H. Akca, N. Özyurt, Effects of re-curing on microstructure of concrete after high temperature exposure, Constr. Build. Mater. 2018; 168, 431-441. https://doi.org/10.1016/i.conbuildmat.2018.02.122

[7] X. Liang, C. Wu, Y. Su, Z. Chen, Z. Li, Development of ultra-high-performance concrete with high fire resistance, Constr. Build. Mater. 2018; 179, 400-412. https://doi.org/10.1016/i.conbuildmat.2018.05.241

[8] I. Yüksel, R. Siddique, Ö. Özkan, Influence of high temperature on the properties of concrete made by industrial by-products as fine aggregate replacement, Constr. Build. Mater. 2011; 25 (2) 967-972. https://doi.org/10.1016/j.conbuildmat.2010.06.085

[9] Çelik, K., (2005). Uçucu Kül, Yüksek Fırın Cürufu ve Traslı Çimentolarla Üretilen Aynı Mukavemet Sınıfındaki Harçların Dayanım ve Dayanıklılığının İncelenmesi. İstanbul Üniversitesi, Fen Bilimleri Enstitüsü, Yüksek Lisans Tezi, 62s, İstanbul.

[10] Yetgin, Ş. ve Çavdar A., (2005). Doğal Puzolan katkı Oranının Çimentonun Dayanım, İşlenebilirlik, Katılaşma ve Hacim Genleşmesi Özelliklerine Etkisi. Fırat Üniversitesi Fen ve Mühendislik Bilimleri Dergisi, 17 (4), 687-692.

[11] Dalkılıç, S., (2014). Tuğla Tozu Katkılı Harçlarda Donatı Korozyonunun Araştırılması. Süleyman Demirel Üniversitesi, Fen Bilimleri Enstitüsü, Yüksek Lisans Tezi, 2-15s

[12] Görçiz, G. "Ülkemizde Tuğla ve Kiremit Endüstrisi", 2000'li Yıllarda Sağlıklı ve Güvenli Konutlar için Tuğla-Kiremit Paneli, TUKDER, Ankara, Ocak, 2000.

[13] Aksin, E., (2007). Endüstriyel Atıklarının Tuğla ve Kiremit Üretiminde Değerlendirilmesi. Dokuz Eylül Üniversitesi, Fen Bilimleri Enstitüsü, Yüksek Lisans Tezi, 89s, İzmir.

[14] Bıyık, M., (2007). BaCO3 ve SrCO3 Katkısıyla Tuğla Üretiminde Çiçeklenmenin Giderilmesi. Afyon Kocatepe Üniversitesi, Fen Bilimleri Enstitüsü., Yüksek Lisans Tezi, 155s, Afyonkarahisar.

[15] Şahin, Ş.E., (2008). Ham ve Kalsine Kolemanit Atıklarının Tuğla Yapımında Kullanım Olanaklarının Araștırılması. Dumlupınar Üniversitesi, Fen Bilimleri Enstitüsü, Yüksek Lisans Tezi, 79s, Kütahya.

[16] Çakar, B., (2009). Esnek Üst Yapılarda Tuğla Kırığı Atıkları Kullanımının Deneysel Olarak İrdelenmesi, Yüksek Lisans Tezi, Eskişehir Osmangazi Üniversitesi, Fen Bilimleri Enstitüsü, İnşaat Mühendisliği Anabilim Dalı, Eskişehir.

[17] 0. Arioz, Effects of elevated temperatures on properties of concrete, Fire Saf. J. 2007; 42 (8), 516-522. https://doi.org/10.1016/j.firesaf.2007.01.003

[18] D. Gavin, F. Pesavento, A. Schrefler, Modelling of deformations of high strength concrete at elevated temperatures, Mater. Struct. 2004; 37 (4), 218-236. https://doi.org/10.1007/BF02480631

[19] S. Aydın, B. Baradan, Effect of pumice and fly ash incorporation on high temperature resistance of cement-based mortars, Cem. Concr. Res. 2007; 37, 988-995. https://doi.org/10.1016/i.cemconres.2007.02.005

[20] W.M. Lin, T.D. Lin, L.J. Powers, Microstructures of fire-damaged concrete, ACI Mater. J. 1996; 93 (3), 199-205. https://doi.org/10.14359/9803

[21] A. Mendes, J.G. Sanjayan, F. Collins, Effects of slag and cooling method on the progressive deterioration of concrete after exposure to elevated temperatures as in a fire event, Mater. Struct. 2011; 44, 709-718. https://doi.org/10.1617/s11527-010-9660-2

[22] D.N. Crook, M.J. Murray, Regain of strength after firing of concrete, Mag. Concr. Res. 1970; 22 (72), 149-154. https://doi.org/10.1680/macr.1970.22.72.149

[23] Y.F. Fu, Y.L. Wong, C.A. Tang, C.S. Poon, Thermal induced stress and associated cracking in cement-based composite at elevated temperatures - Part II: Thermal cracking around multiple inclusions, Cem. Concr. Compos.2004; 26 (2), 99-111. https://doi.org/10.1016/S0958-9465(03)00086-6

[24] TS EN 197-1, (2012). Cement- Stage 1: General cements - component, TSE, Ankara Turkey. using the orthogonal design method, Constr. Build. Mater. 2012; 31, 289-293 https://doi.org/10.1016/j.conbuildmat.2012.01.002 
[25] TS EN 1008, (2003). Beton-Karma suyu-Numune alma, deneyler ve beton endüstrisindeki işlemlerden geri kazanılan su dahil, suyun, beton karma suyu olarak uygunluğunun tayini kuralları TSE, Ankara Turkey.

[26] Yaşar, E.\& Erdoğan Y. 2005; Asidik (Nevşehir) ve Bazik (Osmaniye) Pomzaların Yapı Sektöründe Değerlendirilmesi, 409,413 s.

[27] Khalaf, F.M. and DeVenny, A.S., 2004, Recycling of demolished masonry rubble as coarse aggregate in concrete: review, Journal of Materials in Civil Engineering, 16, 4, 33-340 [28] Z. Ge, Z. Gao, R. Sun, L. Zheng, Mix design of concrete with recycled clay-brickpowder. https://doi.org/10.1061/(ASCE)0899-1561(2004)16:4(331)

[29] TS EN 13369, (2018). Öndökümlü beton mamuller- Genel kurallar TSE, Ankara Turkey,

[30] TS EN 1015-3, (2000). Kagir harcı-Deney metotları- Bölüm 3: Taze harç kıvamının tayini TSE, Ankara Turkey,

[31] TS EN 1015-3, (2000). Kagir harcı-Deney metotları- Bölüm 3: Taze harç kıvamının tayini TSE, Ankara Turkey,

[32] TS EN 1170-6, (1999). Ön yapımlı beton mamuller-Cam elyaf takviyeli çimento (ctc) deney metodu-Bölüm 6: Suya daldırma yoluyla su emme ve kuru yoğunluk tayini TSE, Ankara Turkey,

[33] TS EN 12390-4, (2002). Beton-Sertleşmiş beton deneyleri-Bölüm 4: Basınç dayanım Deney makinelerinin özellikleri TSE, Ankara Turkey.

[34] TS EN 196-1, (2016). Çimento deney metotları-Bölüm 1: Dayanım tayini TSE, Ankara Turkey,

[35] TS EN 12504-4 (2004). Beton deneyleri-Bölüm 4: Ultrases geçiş hızının tayini TSE, Ankara Turkey.

[36] TS EN 13501-1+A1, (2013). Yapı mamulleri ve yapı elemanları, yangın sınıflandırması bölüm 1: Yangın karşısındaki davranış deneylerinden elde edilen veriler kullanılarak sinıflandırma TSE, Ankara Turkey. 